\begin{tabular}{|c|c|}
\hline 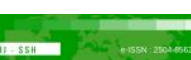 & Malaysian Journal of Social Sciences and Humanities (MJSSH) \\
\hline Malaysian Journal of & Volume 5, Issue 12, December 2020 \\
\hline (MJ-SSH) & e-ISSN : 2504-8562 \\
\hline & $\begin{array}{l}\text { Journal home page: } \\
\text { www.msocialsciences.com }\end{array}$ \\
\hline
\end{tabular}

\title{
Mobile Learning Adoption: A perspective from a Form Six Students in Sabah, Malaysia
}

\author{
Jol bin Kankok ${ }^{1}$, Abdul Said bin Ambotang1, Nurjannah Fatin Amirah Bt Kariming ${ }^{2}$ \\ ${ }^{1}$ Faculty of Education and Psychology, University Malaysia Sabah (UMS) \\ ${ }^{2}$ Centre of Form Six, SMK Merotai Besar, Tawau, Sabah \\ Correspondence: Jol bin Kankok (jolkankok@gmail.com)
}

\begin{abstract}
Despite the availability of studies on mobile learning adoption, its theoretical foundations have not yet matured. However, studies on mobile learning adoption in the context of form six student in Malaysia is still very limited. Against this concern, a study was conducted with the aim of investigating factors that could influence the adoption of mobile learning. Based on The Unified Theory of Acceptance and Use of Technology (UTAUT) and two other variables which are Perceived Playfulness and Self-Directed Learning, an empirical structured has been developed to identify predictors of mobile learning. A self administered questionnaire was adopted and a total of 314 responses were employed for the analysis, using Structural Equation Modelling (SEM). The findings of the analysis revealed that all key constructs (except social influence) affect mobile learning adoption among form six students. Besides that, SelfDirected Learning become the strongest predictor and followed by Effort Expectancy. These findings provide crucial implications for educators and practitioners to take individual characteristic (SelfDirected Learning) into consideration while promoting mobile learning. This study represents one of the few attempts to reveal the extended UTAUT model could be increased explanation power of technology acceptance by the users. Directions for future study are suggested at the end of the paper.
\end{abstract}

Keywords: mobile learning adoption, unified theory of acceptance and use of technology, perceived playfulness, self-directed learning

\section{Introduction}

Mobile learning acceptance and adoption is gaining traction in popularity around the world due to the increasing and availability of low-cost mobile devices and supporting mobile technology infrastructure (Jalil et al. 2015). The pervasive existence of these technologies makes mobile learning ideal for developing countries since there is lack of advanced training technologies (Okai et al. 2020). Generally, mobile learning studies focused on developing countries (Okai et al. 2017; Kaliisa et al. 2017; Lamptey et al. 2017) have shown that mobile technology has great potential to expand educational opportunities in the region. Finding of these investigations show that mobile learning has the potential to become a reliable instructional tool in higher education sector and could help attain technology-enhanced teaching and learning benefits hindered by the digital divide. Indeed, the prospect has been investigated from various perspectives. While some studies have considered technology design (Grant et al. 2019; Suartama et al. 2019), most studies have focused on students' perception, their ownership of mobile 
devices and willingness for mobile learning adoption (Abdullah et al. 2019; Kumar \& Chand, 2019; Masrek \& Shahibi, 2019; Ramakrisnan et al. 2019).

Along with mobile technology expansion, the emergence of mobile learning has resulted in the revolution of the of distance learning. Therefore, mobile learning is popularly described as a learning process which taking advantage of mobile devices, ubiquitous communications technology and intelligent user interfaces (Masrek \& Shahibi, 2019). Generally, mobile learning helps educational institutions to expand the accessibility, inter connection and reusability of learning resources, also to enhance flexibility and interactivity of learning behaviour at appropriate times and places (Alam \& Aljohani, 2020). Besides that, mobile learning could encourage the use of previously unproductive time, allow learning behaviours irrespective of time and place and provide great opportunities for personalized, customize and contextaware learning support services (Erazo et al. 2019; Curum \& Khedo, 2019). However, the availability of mobile learning does not guarantee that it will be accepted by the users or learners, especially when it comes to supportive tools for the learning. Despite its strong penetration into the education system, there is no assurance that it will be accepted as a learning medium by students. As a matter of fact, the understanding of the adoption of mobile technologies in educational environments is still in its incipient stage.

Indeed, mobile learning has not been formally integrated into the delivery of form six level in Malaysia. In the same way for e-learning in general, but e-learning technologies are being used by students and teachers (Thomas et al. 2013). In this context, mobile devices also have the potential to be integrated into form six education. However, in addition to the infrastructure and other physical requirements, the adoption of mobile learning will depend on human factors including skills, attitude and culture (Mustafa et al. 2018; Kukulska et al, 2007). Studies of mobile learning adoption in form six level are therefore important since they will help to identify the important drivers of adoption.

According to Grant (2019) and Shorfuzzaman et al. (2019), while there were huge studies on mobile learning, its theoretical foundations were still immature. Thus, questions on how mobile learning can be promoted are still largely unresolved. Hence, by having this study, it could hopefully fill the gap on the absence of mobile learning in form six students. The findings could be new learning discoveries which would provide some beneficial insights on how the mobile learning as a new learning tool could be useful in helping form six students in improving their learning based. Against this background, a study was conducted with the following objectives:

i. to identify factors that influence ML adoption among form six students,

ii. to ascertain whether the following factors correlate to use behaviour of mobile learning: performance expectancy, effort expectancy, social influence, facilitating conditions, perceived playfulness and Self-Directed Learning,

iii. to evaluate the influence of these factors towards use behaviour.

\section{Literature Review}

According to Grant (2019) mobile learning generally contains four categories of definitions, there are relationship to distance education and e-learning, exploitation of devices and technologies, mediation with technology, and nomadic nature of learner and learning. While, the most acceptance of mobile learning definitions are the using of mobile technology to facilitate, support, enhance and extend the reach of teaching and learning. Based on its characteristics, mobile learning is said to be ubiquitous, personal, collaboratives and instant information (Zhang, 2019). As a result, the advantages of mobile learning are (Mabruri et al. 2019; Uther, 2019):

i. $\quad$ just-enough learning - highly applied, easily digestible learning

ii. just-in-time learning - convenient, flexible and relevant learning at the exact moment learning is required

iii. just-for-me learning - learner-driven learning in a suitable format 
iv. cost-saving - mobile learning can be cost effective and using a learner's own mobile device eliminates technological barriers to accessing learning.

In addition, mobile learning research ought to examine the relationship between learners and their learning context. This study attempts to explore factors that motivate learners to use mobile learning in both formal and informal learning contexts. Although mobile technology was utilized very differently in both learning contexts (Laurillard, 2007), previous research does not differentiate between learners' adoption to use mobile learning in formal and informal settings. In fact, focus of existing literature is mainly on formal learning (Looi et al., 2016) in which mobile learning platforms are used frequently for learning activities (see for example Wang et al. 2009; Liu et al., 2010). However, learners not only use virtual learning platforms but also access online information to facilitate their learning. Despite being informal, this is an important aspect of learning process. However, there is insufficient empirical evidence for mobile learning usage in informal learning context (Jones, Scanlon, \& Clough, 2013). This could be due to the difficulty of capturing use of technology in this context (Pachler, 2007). As the design of mobile learning activities for informal contexts is scaling up (Looi et al., 2014), this environment needs further investigation (Kearney et al. 2012). Moreover, it is known that individual differences of learners affect self-directed learning (Kreber, 1998). Extant research neglects the influences of individual characteristics on mobile learning usage which is highly dependent on self-direction. This study contributes to current literature by considering and examining the relationship between the context of learning and learners' characteristics.

Since the dawn of mobile learning, scholars have been studying factors that influence its adoption. Theories, models or framework such as Theory of Reasoned Action (TRA); Social Cognitive Theory (SCT); Technology Acceptance Model (TAM); Theory of Planned Behaviour (TPB); Model of PC Utilization (MPCU); Innovation Diffusion Theory (IDT); and The Unified Theory of Acceptance and Use of Technology (UTAUT) have been referred and adapted by researchers to investigate the adoption of mobile learning(Masrek \& Shahibi, 2019). Among the various theories and models, UTAUT was found to be the most adopted or referred in the context of mobile learning. The literature suggests that UTAUT could explain up to 70\% variances of technology acceptance behaviour (Venkatesh et al. 2003). UTAUT identified four key constructs which are performance expectancy, effort expectancy, social factors and facilitating conditions to have a direct influence on intention to adopt technology. Previous mobile learning studies have constantly shown the contribution of these four constructs.

However, Pedersen \& Ling (2003); Wang et al. (2009) and Karimi (2016) argued, the main constructs of UTAUT may not be fully applicable to mobile learning adoption. Indeed, testing and verification of this model by modifying it and extending it with other determinants is essential. This paper follows the above literature and proposes and empirically tests an alternative mobile learning adoption model for specific learning contexts. Besides these four constructs, researchers have also explored the role of perceived playfulness and self-directed of learning. The reason for including perceived playfulness was because the features of the applications in the mobile learning environment were generally fun to explore and engage, making the users fully absorbed in their use (Masrek \& Shahibi, 2019). On the other hand, self-directed learning was also studied because mobile learning environment promotes self-management learning or student-centred learning (Karimi et al. 2016; Lin et al, 2016). Thus, the mobile learning is best suited for learners or students who are very independent or being supervised or facilitated minimally by the instructors.

Venkatesh et al. (2003) suggested that performance expectancy, effort expectancy, social influence and facilitating conditions have are direct determinants of technology behavioural intention. Even so, some studies of mobile learning have incorporated new concepts of perceived playfulness and self-directed of learning into this model. While playfulness was consistently found influential, results for self-directed learning are contradictory. A study by Wang et al., (2009) reported a significant effect whereas Lowenthal (2010) did not found a significant influence. Therefore, the influence of self-directed learning as a significant determinant for mobile technology adoption, should be given more attention. Drawing upon this premise, the present study will investigate the factors that influence the adoption of mobile learning as shown in Figure 1. 
Figure 1: Theoretical Framework

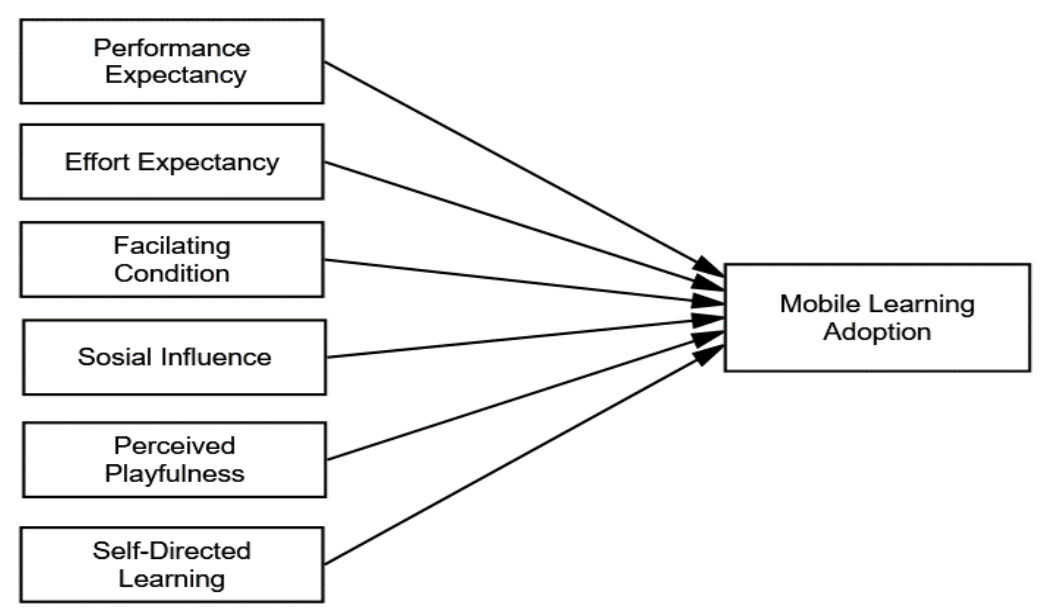

\section{Mobile Learning Adoption}

There are various of acceptance technology models have been previously developed to examine users' acceptance and intention to adopt a new technology. Recently, these models have found their way to studies of e-learning and mobile learning. Among of them, the unified theory of acceptance and use of technology (UTAUT), proposed by Venkatesh, Morris, Davis, and Davis (2003), has been widely used in this line of studies (Ariffin \& Lim, 2020; Wong et al., 2019; Yip et al. 2018). This comprehensive model integrates eight prominent models of technology acceptance, including of Theory of Reasoned Action (TRA) (Fishbein \& Ajzen, 1975), Technology Acceptance Model (TAM) (Davis, 1989), Theory of Planned Behaviour (TPB) (Ajzen, 1991), combined TAM and TPB (C-TAM-TPB) (Taylor \& Todd, 1995a), Motivational Model (MM) (Davis, Bagozzi, \& Warshaw, 1992), the model of PC utilisation (MPCU) (Thompson, Higgins, \& Howell, 1991), Innovation Diffusion Theory (IDT) (Moore \& Benbasat, 1991; Rogers, 2003) and Social Cognitive Theory (SCT) (Bandura, 1986). Later, the UTAUT has been proved to provide an excellent framework to identify the determinants of technology acceptance intentions and adoption in the literature (Gupta et al., 2018; Venkatesh et al., 2012; Wang et al., 2010).

Based on the UTAUT theory, this study emphasizes on adoption of mobile learning in term of usage behaviour. According to Ajzen and Fishbein (1975), behavioural intention will lead to use behaviour. Therefore, when consumers have high technology adoption levels, such technology-use behaviour is likely to be triggered. As described, use behaviour refers to the frequency of actual use of information technology by the users (Ramírez et al. 2019). Besides, users with more experience will have more tendencies to strengthen their habit because they have spent more time to process cues and to carry out the associated behaviour (Kim \& Malhotra, 2005). In addition, routine behaviour become automated and guided further by associated cues with more experience (Jasperson et al., 2005). As a result, the impact of behavioural intention on technology use will reduce when more experience is gained.

Therefore, we use actual behaviour as a final dependent variable rather than intention as usual. The goal here is to understand usage as the dependent variable instead using of intention as a predictor of use behaviour (Venkatesh et a. 2003). While, most of the study focussed on intention behaviour to predict the usage of mobile learning, this study focuses on factors that directly influence the actual use behaviour. Some researchers determine significant impact, such as Ahmad (2014), Nistor et al. (2013) and Teo (2001). Moreover, Nistor et al. (2013) described that habits and high computer literacy could overshadowed intention behaviour because of the unique characteristic of the respondents as a millennial generation. Thus, this study tries to investigate factors that could influence actual usage directly in term of mobile learning adoption. All these explanations presume, however, that technology adoption is a rationale decision as conceptualized by Ajzen \& Fishbein (2000). 


\section{Performance Expectancy}

Performance expectancy, which is described by Venkatesh et al. (2012), refers to "the degree to which an individual believes that using mobile learning will help him or her to attain gains in job performance". Adapting performance expectancy to mobile learning suggests that users will find it useful because it enables learners to accomplish learning activities effectively and flexible (Masrek \& Shahibi, 2019). It is one of the most significant determinants for technology adoption (Mohd Azli et al., 2019; Amzauorou \& Oubaha, 2018) and use behaviour (Duarte \& Pinho, 2019; Alrawashdeh et al., 2012; Yu, 2012). This construct consists of five criteria: extrinsic motivation, perceived usefulness, outcome expectations, job fit and relative advantage (Wong et al. 2020). Extrinsic motivation refers to the perception of the user as to whether to perform an activity when such an activity is recognized as an instrument for achieving different valued outcomes of the activity itself. (Teo et al., 1999; Chong, 2013). On the other hand, perceived usefulness is the degree to which a person assumes that new technology will enhance the efficiency of his or her work. (Davis, 1989). Next, the outcome expectations are the potential outcomes of a user's actions, where expectations concentrate on the outcome benefit and are relative to various individuals (Bandura, 1986). Job fit can be explained as how technologies can improve people's work efficiency. (Thompson et al., 1991; Jeng \& Tzeng, 2012). Lastly, The relative benefit of the adoption of a new technology product over the cost (Rogers, 1962). Based on Oliver's (1980) Expectation Confirmation Theory (ECT), when the expectation of a user is confirmed, satisfaction will follow. In the context of availability of various task environments, performance expectancy affects intention to use (Baptista \& Oliveira, 2015). Therefore, performance expectancy is posited to affect the adoption of mobile learning. It is one of the key factors affecting technology adoption. Following the findings of the aforesaid studies, this study expects that performance expectancy is a significant predictor of the mobile learning adoption. Therefore, it is hypothesized that: H1: Performance expectancy significantly affects intention to adopt mobile learning.

\section{Effort Expectancy}

Effort expectancy is "the degree of ease associated with the use of the system" (Venkatesh et al. 2012). In the context of mobile learning, effort expectancy is about an individual's expectation of using mobile learning without much effort. The easier the mobile learning applications can be accessed by the user, the more is the intention to adopt it. This suggests that effort required will strengthen the intention to use a certain technology (Sivathanu, 2019). In fact, the performance and the effort expectancies are two major salient predictors of use technology behaviour (Davis, 1989; Casey and Wilson, 2012). Studies across different countries showed inconsistency findings of effort expectancy influence on intention to adopt mobile learning. While Botero et al. (2018); Kissi et al. (2018); Jambulingam (2013) did not find any support, others, such as Nawi et al. (2019); Norjanah et al. (2018); Hadi \& Kishik (2014); Iqbal \& Qureshi (2014); Momani \& Abualkishik (2014) found a positive relationship between effort expectancy and intention to adopt mobile learning. In the case of this study, the researcher argued that effort expectancy is an influential factor for adopting mobile learning. Accordingly, this study posits that: $H 2$ : Effort expectancy significantly affects intention to adopt mobile learning.

\section{Social Influence}

According to Venkatesh et al. (2003), social influence is defined as "the degree to which an individual perceives that important others believe he or she should use the new system'. It is also defined as the internalization of the subjective culture of the reference groups by the individual and the specific interpersonal agreements that the individual has made with other in specific social situations (Botero et al. (2018). Besides that, current study identified social influence as the degree to which students perceive educational stakeholders (teachers, students, parents) believe that they should benefit mobile technology in their learning. There are interesting findings on the impact of social influence on mobile learning use behaviour. Van Schaik (2009) stated that the impact of social influence become stronger when there is limited experience with the technology. Durak (2019), Huang \& Wu (2017) and Pedro et al. (2017) revealed the significant impact of this factor on intention and use behaviour. However, the impact of social influence remains inconclusive in directly predicting the degree of usage behaviour. Other studies 
suggested some inconsistencies such as Daktuk et al. (2018); Kissi et al. (2018) and Yakubu \& Dasuki (2018). Accordingly, the following hypothesis is proposed: H3 Social influence (SI) is positively related to $B I$.

\section{Facilitating Condition}

Facilitating condition is defined as "the degree to which an individual believes that an organizational and technical infrastructure exists to support the use of the system"(Venkatesh et al. 2012). Acceptance of any new technology is highly dependent upon the supporting conditions or environment. In the context of mobile learning, these conditions of facilitation may appear in the form such as resources, knowledge, Internet speed, guidance, help and training (Sivathanu, 2019). Yet, in the learning context, resources are considered the most crucial determinant. In many mobile learning applications, the content does not fulfil the needs of the students or users (Masrek \& Shahibi, 2019). Just like any form of computer-based information systems, the application should follow a rigorous process, to ensure the content are highly usable and meeting the needs of the users (Wong et al. 2019). A study reported by Kissi et al. (2018); Maita et al. (2018); Mosunmola et al. (2018); Iqbal \& Qureshi, (2012) showed that facilitating condition was a significant predictor of mobile learning adoption. However, some researchers suggested that this factor could be given insignificant impact to usage behaviour because of some circumstances such as high of computer self-efficacy and computer literacy, good infrastructures, family background (Durak, 2019; Yang et al. 2019; Pedro et al. 2017). Given this background, this study postulates that: H5: Facilitating conditions significantly affect intention to adopt ML.

\section{Perceived Playfulness}

Perceived playfulness is defined as the individual perceives that his or her attention is focused on the interaction with certain technologies, high curiosity during interaction and finds the interaction intrinsically enjoyable or interesting (Moon \& Kim, 2001). They suggested that perceived playfulness will provide intrinsic motivation, which is shaped by individual's experiences with the environment. While, intrinsic motivator refers to the individual's engagement in an activity due to his or her interest (Ryan \& Deci, 2000). Because of that, researchers considered perceived playfulness as one of the critical factors that could potentially affect learning engagement with the utilization of new teaching innovations and technology (Chou, 2006; Chung \& Tan, 2004). Previous studies have also shown that the use of information technology is influenced by perceived playfulness (Masrek et al. 2019; Nawi et al. 2019; Iqbal \& Qureshi, 2012). The reason $\mathrm{n}$ is because individuals who experience pleasure or enjoyment from using an information technology or information systems are more likely to intend to use it extensively than those who do not (Schofield \& Taylor, 2011). Taken the above together, the researcher argued that this situation would also be applicable to the context of mobile learning adoption. Hence, the study hypothesizes: H4 - Perceived playfulness significantly affects individual intention to adopt $M L$.

\section{Self-directed Learning}

Knowles (1975) defines self-directed learning as "a process in which individuals take the initiative, with or without the help from others, in diagnosing their learning needs, formulating goals, identifying human and material resources, choosing and implementing appropriate learning strategies, and evaluating learning outcomes. "In the context of learning, this implied that "learning should empower a student to become a free, mature, and authentic self" (Savin \& Major, 2004). This suggest that mobile learning is largely self-directed and learners "find their own way to make a learning situation personalized and sensitized to them" (Park et al. 2010). Learners are active and central participants in this process. Therefore, learners take self- initiative, with or without the help from others, in doing their learning activities. Therefore, researchers stress the importance of enabling learners to have more control over their own learning. As a result, mobile learning offers learners the opportunity to be at the centre of the learning process, to play an active role from determining their goal to the assessment stage (Makoe, 2010). When they are actively engaged with the task, they are more likely to develop learning strategies to enhance their learning outcomes and thus increase their motivation. Unlike other digital media, a mobile device can be used all the time and allows great control to user on how and when to 
access their devices (Karimi, 2016). Thus, previous studies suggested that self-directed learning should be taken into consideration while examine mobile learning readiness $(\mathrm{Gu}, 2016$; Lin et al, 2016; Williams \& Brown, 2013). On the other hand, Masrek et al. (2019) and Karimi (2016) tested this antecedent into mobile learning adoption and surprisingly found a significant influence. Due to its significant effect, self-directed learning has been included in the model and hypothesize as: H6 - SelfDirected Learning significantly affects individual intention to adopt mobile learning.

\section{Methodology}

This study employed a quantitative approach with a survey as the research method. The instrument used for data collection was a questionnaire. The questionnaire was developed by referring to the instruments used by previous studies. In particular, the instruments used by Masrek \& Shahibi (2019); Lin et al. (2016); Mazharuddin (2014); Williams \& Brown (2013); Iqbal \& Qureshi (2012); Wang et al. (2009) and Venkatesh et al. (2003) were adapted as these studies were also focusing on mobile learning and information technology adoption. Likert scale items (ranging from 1=Strongly Disagree to 5=Strongly Agree) were utilized. As shown in Table 1, a total of 21 items were used for measuring the variables. The questionnaire was validated by several experts before pre-tested data collection done by prospective respondents. Some items were revised based on expert suggestion.

Table 1: Sources of Measurement

\begin{tabular}{lll}
\hline Variable & $\begin{array}{c}\text { No of } \\
\text { items }\end{array}$ & Source of Instrument \\
\hline Performance Expectancy & 3 & Venkatesh et al. (2003) \\
Effort expectancy & 3 & Venkatesh et al. (2003) \\
Social influence & 3 & Venkatesh et al. (2003) \\
Facilitating conditions & 3 & Venkatesh et al. (2003) \\
Perceived playfulness & 3 & Wang et al. (2009), Masrek \& Shahibi (2019) \\
Self-Directed Learning & 3 & Lin et al. (2016), Williams \& Brown (2013) \\
Use Behaviour & 3 & Iqbal \& Qureshi (2012), Mazharuddin (2014) \\
\hline
\end{tabular}

The population of the study was Economics form six students in Sabah, Malaysia. Using the listing of registered students as the sampling frame, the simple random sampling technique was adopted to identify the targeted respondents. A total of 340 questionnaires was sent to the targeted students using printed (paper-based) and online surveyed. A total of 320 questionnaires was returned. However, 6 were found to be unusable for further analysis as they were incomplete. The remaining 314 were analysed using IBM SPSS Amos version 24. The structural equation modelling (SEM) analyses were carried out for assessing the constructs validity and reliability. The result and detail of constructs validity, reliability and hypotheses testing will discuss in the finding section.

\section{Result}

\section{Demographic profiles}

Respondents' demographic profiles were summarized in Table 1. As can be seen, majority of respondents were female (64\%) compare to male (46\%). In term of ethnicity, $69 \%$ respondents were Malay, followed by Chinese (27\%) and others ethnic were only $4 \%$. As for devices ownership, most respondents have their own hand phone ( $82 \%$ ) whereby laptop (12\%) and only $6 \%$ own a tablet. Majority of respondents reported have their own internet subscription (94\%). 
Table 2: Demographic Profiles

\begin{tabular}{lc}
\hline \multicolumn{1}{c}{ Variables } & $\mathbf{N}(\%)$ \\
\hline Gender & 38 \\
Male & 62 \\
Female & \\
Ethnicity & 69 \\
$\quad$ Malay & 27 \\
Chinese & 4 \\
Others & \\
School category & 72 \\
$\quad$ City & 28 \\
Rural & \\
Type of Devices & 84 \\
Hand Phone & 4 \\
Tablet & 12 \\
Laptop & \\
Internet subscription & 98 \\
Yes & 2 \\
No & \\
\hline
\end{tabular}

\section{Construct Validity and Reliability Assessment}

The study adopted the two-steps approach of modelling and analysing the structural model namely, confirmatory Factor Analysis (CFA) and Structural Equation Modelling (SEM). Thus, prior to modelling the structural model and executing Structural Equation Modelling (SEM), the study needs to validate all measurement models of latent constructs for Unidimensional, Validity and Reliability (Awang, 2015; Awang et al., 2015 and Afthanorhan et al,, 2017, 2017a). This validation procedure is called Confirmatory Factor Analysis (CFA). According to Awang (2015) and Awang et al. (2015), the measurement model of latent constructs needs to pass three types of validity namely Construct Validity, Convergent Validity, and Discriminant Validity. The Construct Validity is assessed through the Fitness Indexes of the Measurement Model, the Convergent Validity is assessed through computing the Average Variance Extracted (AVE), and Discriminant Validity is assessed through developing the Discriminant Validity Index Summary. As for the reliability, it is adequate for the study to assess the Composite Reliability (CR) since it replaced the traditional method of computing the Cronbach Alpha for analysis using Structural Equation Modelling (SEM) (Aziz et al., 2016; Mohamad et al., 2017, 2018). The latent construct is considered valid if its fitness indexes achieved the three Model Fit categories namely Absolute Fit, Incremental Fit and Parsimonious Fit (Awang et al., 2015; Yusof et al., 2018). The threshold and its respective index are given in Table 3.

Table 3: Model Fit Categories and their level of acceptance

\begin{tabular}{lll}
\hline Name of category & Name of Index & Leve of acceptance \\
\hline Absolute Fit Index & RMSEA & RMSEA $<0.08$ \\
& GFI & GFI $>0.90$ \\
Incremental Fit Index & AGFI & AGFI $>0.90$ \\
& CFI & CFI $>0.90$ \\
& TLI & TLI $>0.90$ \\
& NFI & NFI $>0.90$ \\
Parsimonious Fit Index & Chisq/df & Chi-Square $/$ df $<3.0$ \\
& & \\
\hline
\end{tabular}

***The indexes in bold are recommended since they are frequently reported in literatures Source: Awang (2015) 
The model for this study has six exogenous constructs, and one endogenous construct. The results of the Pooled-CFA procedure for models shown in Figure 2. The output indicates the fitness indexes for all constructs in the model, the factor loading for every item measuring their respective construct, and the correlation between construct in the model. The fitness indexes should meet threshold values as shown in Table 1, the factor loading for every item should be a minimum of 0.5 (Hair et al. 2017) and the correlation coefficient any two constructs should not exceed 0.85 (Yusof et al., 2017; Aziz et al., 2016; Mohamad et al., 2016, 2017, 2018). The problem of multi-collinearity occurs if the correlation between any two constructs exceed 0.85 . Looking at the correlation values (at the double-headed arrow), none of the value found to be greater than 0.85 . Thus, the multi-collinearity problem does not arise.

Figure 2: The Pooled-CFA results showing factor loading and correlation between constructs.

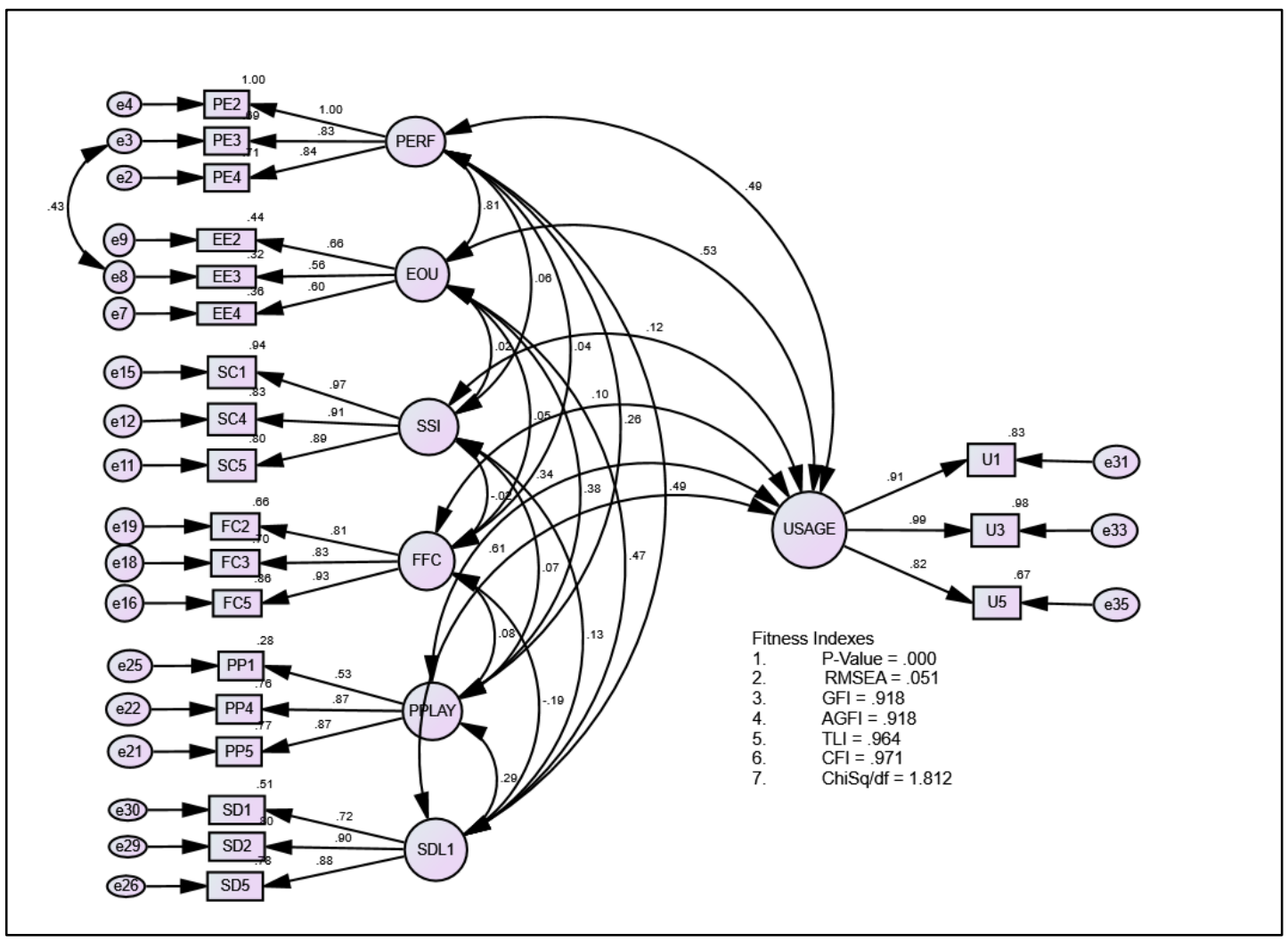

\section{The Assessment for Construct Validity}

The fitness Indexes in Figure4 have met the threshold values as stated in Table 2. The Absolute Fit category namely RMSEA is 0.051 (achieve the threshold of less than 0.08), the Incremental Fit category namely CFI is 0.971 (achieve the threshold of greater than 0.90), and the Parsimonious Fit category namely the ratio of Chisq/df is 1.812 (achieve the threshold of less than 3.0). Thus, the measurement model of all latent constructs in Figure 2 have achieved the requirement for Construct Validity (Awang, 2015; Yusuf et al., 2017, 2018).

\section{The Assessmentfor Convergent Validity and Composite Reliability}

For the assessment of Convergent Validity, the study needs to compute Average Variance Extracted (AVE). The construct achieved Convergent Validity if its AVE exceeds the threshold value of 0.5 (Awang, 2014; 2015). As for assessing the Composite Reliability, the study needs to compute the CR and its value should exceed the threshold value of 0.6 for this reliability to achieve (Aziz et al., 2016; Yusof et., 2017; Mohamad et al., 2016, 2017, 2018).

The AVE and CR for all constructs are computed and presented in Table 3 for independent constructs and Table 4 for dependent construct. 
DOI: https://doi.org/10.47405/mjssh.v5i12.563

Table 4: The Average Variance Extracted (AVE) and Composite Reliability (CR)

\begin{tabular}{lcccc}
\hline Construct & Items & $\begin{array}{c}\text { Factor } \\
\text { Loading }\end{array}$ & $\begin{array}{c}\text { CR } \\
\text { (above 0.60) }\end{array}$ & $\begin{array}{c}\text { AVE } \\
\text { (above 0.50) }\end{array}$ \\
\hline \multirow{3}{*}{ Performance Expectancy } & PE2 & 1.00 & & \\
& PE3 & 0.83 & 0.922 & 0.798 \\
& PE4 & 0.84 & & \\
Effort Expectancy & EE2 & 0.66 & & 0.514 \\
& EE3 & 0.56 & 0.637 & \\
Social Influence & EE4 & 0.60 & & 0.854 \\
& SC1 & 0.97 & & \\
Facilitating Conditions & SC4 & 0.91 & 0.946 & 0.737 \\
& SC5 & 0.89 & & \\
Perceived Playful & FC2 & 0.81 & & 0.667 \\
& FC3 & 0.83 & 0.893 & \\
Self-Directed Learning & FC5 & 0.93 & & 0.701 \\
& PP1 & 0.53 & & \\
& PP4 & 0.87 & 0.810 & \\
Usage & PP5 & 0.87 & & 0.934 \\
& SD1 & 0.72 & & \\
\hline
\end{tabular}

With reference to the Average Variance Extracted (AVE) and Composite Reliability (CR) values in Table 3, the study found all AVE and CR exceed their threshold values of 0.5 and 0.6 respectively (Yusof et., 2017, Aziz et al., 2016; Mohamad et al., 2016, 2017, 2018).Thus, the study can conclude that the Convergent Validity and Composite Reliability for all latent constructs in the model have been achieved.

\section{The Assessment of Discriminant Validity among Constructs}

The study needs to assess another type of validity for the model namely, discriminant validity. This validity assessment is to ensure that no redundant constructs occur in the model. Redundant construct occurs when any pair of constructs in the model are highly correlated. For assessing the discriminant validity, one needs to develop the discriminant validity index summary as shown in Table 5 . The diagonal values in bold are the square root of the AVE of the respective constructs while other values are the correlation coefficient between the pair of the respective constructs.

Table 5: The Discriminant Validity Index Summary for all Constructs

\begin{tabular}{|c|c|c|c|c|c|c|c|}
\hline Construct & $\begin{array}{l}\text { Performance } \\
\text { Expectancy }\end{array}$ & $\begin{array}{c}\text { Effort } \\
\text { Expectancy }\end{array}$ & $\begin{array}{l}\text { Social } \\
\text { Influence }\end{array}$ & $\begin{array}{l}\text { Facilitating } \\
\text { Condition }\end{array}$ & $\begin{array}{c}\text { Perceived } \\
\text { Playful }\end{array}$ & $\begin{array}{c}\text { Self- } \\
\text { Directed } \\
\text { Learning }\end{array}$ & Usage \\
\hline $\begin{array}{l}\text { Performance } \\
\text { Expectancy }\end{array}$ & 0.89 & & & & & & \\
\hline $\begin{array}{l}\text { Effort } \\
\text { Expectancy }\end{array}$ & 0.81 & 0.72 & & & & & \\
\hline $\begin{array}{l}\text { Social } \\
\text { Influence }\end{array}$ & 0.06 & 0.02 & 0.92 & & & & \\
\hline $\begin{array}{l}\text { Facilitating } \\
\text { Condition }\end{array}$ & 0.04 & 0.05 & -0.02 & 0.85 & & & \\
\hline $\begin{array}{l}\text { Perceived } \\
\text { Playful }\end{array}$ & 0.28 & 0.38 & 0.07 & 0.08 & 0.67 & & \\
\hline
\end{tabular}



DOI: https://doi.org/10.47405/mjssh.v5i12.563

\begin{tabular}{llllllll}
\hline $\begin{array}{l}\text { Self- } \\
\text { Directed } \\
\text { Learning }\end{array}$ & 0.49 & 0.47 & 0.13 & -0.19 & 0.29 & $\mathbf{0 . 8 3}$ & \\
Usage & 0.49 & 0.53 & 0.12 & 0.10 & 0.34 & 0.49 & $\mathbf{0 . 9 6}$ \\
\hline
\end{tabular}

Referring to Table 5, the Discriminant Validity of the respective construct is achieved if the square root of its AVE exceeds its correlation value with other constructs in the model. In other words, the Discriminant Validity is achieved if the diagonal values (in bold) are higher than any other values in its row and column. The tabulated values in Table 5 meet the threshold of Discriminant Validity. Thus, the study concludes that the Discriminant Validity for all constructs is achieved.

\section{The Structural Equation Model (SEM) and Hypothesis Testing}

In order to test the developed hypothesis, this study focus on the regression effects of all independent constructs into the dependent construct. In this study, the researcher is modelling the effects of Performance Expectancy, Effort Expectancy, Social Influence, Facilitating Conditions, Perceived Playful and Self-Directed Learning on Mobile Learning Adoption. The output resulted from executing SEM is given in Figure 3 for the Standardized Regression Weights. Apparently, all fit indices surpassed the fit criteria suggesting that the SEM model fits the data very well.

The regression coefficient of the Job Satisfaction and its significance is tabulated in Table 6.

Table 6: Regression Weights: (Default model)

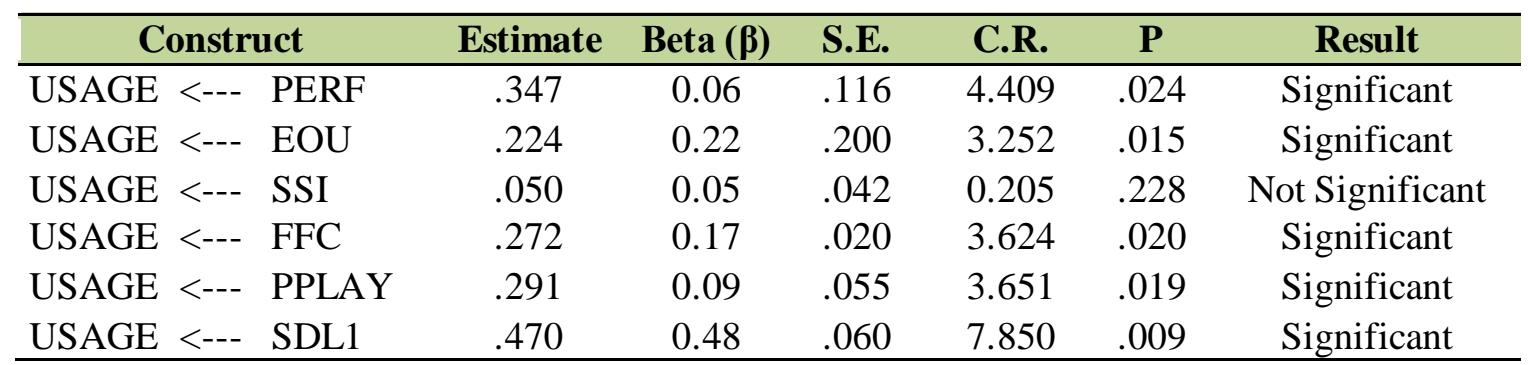

Figure 3: The Standardized Regression Path Coefficient among constructs in the model

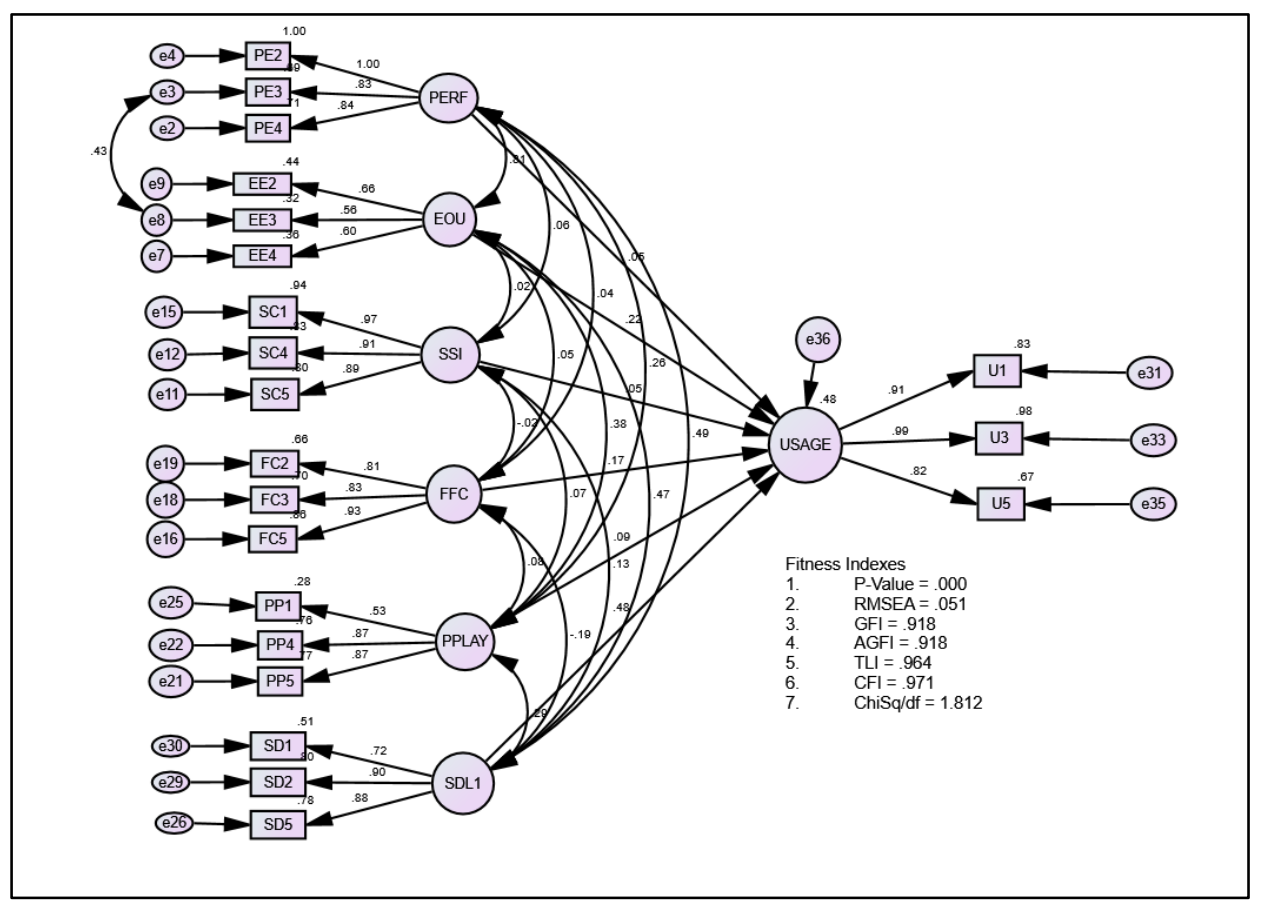


The text output for every direct effect relationship in this study as shown by the model in Figure 3 is presented in Table 7. Based on table above, all independent variables are significantly influence the usage of mobile learning as the p-values for all paths are well below 0.05. Instead for social influence had no effect on mobile learning usage as p-value greater than 0.05 . Further, for the hypothesis testing, result as shown in Table 7 below:

Table 7: Hypothesis Testing

\begin{tabular}{|c|c|c|}
\hline Hypothesis & $\mathbf{P}$ & Result \\
\hline $\begin{array}{l}\text { H1 - Performance Expectancy significantly effects on mobile } \\
\text { learning adoption }\end{array}$ & 0.024 & Supported \\
\hline $\begin{array}{l}\mathrm{H} 2 \text { - Effort Expectancy significantly effects on mobile learning } \\
\text { adoption }\end{array}$ & 0.015 & Supported \\
\hline $\begin{array}{l}\mathrm{H} 3 \text { - Social Influence significantly effects on mobile learning } \\
\text { adoption }\end{array}$ & 0.228 & $\begin{array}{l}\text { Not } \\
\text { Supported }\end{array}$ \\
\hline $\begin{array}{l}\mathrm{H} 4 \text { - Facilitating Conditions significantly effects on mobile learning } \\
\text { adoption }\end{array}$ & 0.020 & Supported \\
\hline $\begin{array}{l}\text { H5 - Perceived playfulness significantly effects on mobile learning } \\
\text { adoption }\end{array}$ & 0.019 & Supported \\
\hline $\begin{array}{l}\text { H6 - Self-Directed Learning significantly effects on mobile learning } \\
\text { adoption }\end{array}$ & 0.009 & Supported \\
\hline
\end{tabular}

The study found five independent constructs in this study namely, Performance Expectancy, Effort Expectancy, Facilitating Conditions, Perceived Playful and Self-Directed Learning provide significant effects on dependent construct Mobile Learning Adoption. However, one independent construct namely, Social Influence does not have significant effects on Mobile Learning Adoption.

\section{Discussion}

The purpose of the study was primarily to broaden the understanding of student's m-learning adoption. Based on the extend UTAUT model, findings are statistically proven that exist significant influences by independent variable into mobile learning adoption among the students. The results generated from the path analysis indicate that the combination of the six independent variables accounts for $48 \%$ of the variance in mobile learning adoption. This result suggests that $48 \%$ of the variance in mobile learning adoption can be explained by performance expectancy, effort expectancy, social influence, facilitating conditions, perceived playful and self-directed learning. However, the prediction power is still considered slightly moderate (Hair et al. 2013) but for the social science, art and psychology context that value still acceptable (Frost, 2013). This could be because of humans and individuals are typically very heterogonous in their attitudes and behaviours (Kelvyn, 2013) and very hard to predict (Ramona, 2016; Stone et al. 2013). In fact, this result in line with Hamidi \& Chavoshi (2018); Abu-Al-Aish \& Love (2013); Iqbal \& Qureshi (2012) which are having lower R-square (below .50) in their result. The lower value explanation could be because of mobile learning is still in infancy for the form six students especially in Malaysia context. They are not fully expose in term of using mobile devices for learning purpose unlike students in higher institutions.

Besides that, result also supported the extension of UTAUT model to expand the understanding of mobile learning adoption as an informal learning strategy. This research showed significant influence existed by adding certain determinants into UTUAT variables in term of understanding information technology acceptance. This result in line with Masrek \& Shahibi, 2019; Mohd Ali et al. (2019); Nawi et al. (2019); Botero et al. (2018); Kissi et al. (2018). These research were extended UTAUT model by including some determinants such as Perceived Playful, Self-Directed Learning, Perceived Risk, Perceived Trust, Attitude, Self-Management Learning and Self-Efficacy. The result verified that extended UTAUT were significantly influence mobile learning adoption yet increase the explanation power or the variance of mobile learning acceptance. 
This study has significantly recognized the influence of performance expectancy on mobile learning adoption $(\beta=0.06, \mathrm{p}<0.05)$. The result is consistent with Nawi et al. (2019); Botero et al. (2018); Brata $\&$ Amalia, (2018); Kissi et al. (2018) and Huang \& Wu (2017). The findings indicate that the more students believe that mobile learning is useful for learning and increases their performance, the more likely they are to become involved in mobile learning. Theoretically, this result further strengthens UTAUT in predicting mobile learning adoption. Just as performance expectancy, effort expectancy which is derived from UTAUT was also found to be a significant predictor of ML adoption $(\beta=0.22, p$ $<0.05$ ). The result is in line with Durak (2019); Yang et al. (2019); Botero et al. (2018) and Thongsri et al. (2017) which means that the more students perceive that mobile learning is easy to use for learning, the more likely they are to engage in mobile learning. Today, the use of mobile devices among form six students of Malaysian, especially smart phones and laptop is very common. Perhaps because the use of a mobile device appears to be routine for most of these students; therefore, they may feel that using it will not require much of their effort, as it is similar to using it for other tasks. Moreover, this determinant was the strongest predictor among the core variable of UTAUT $(\beta=0.22)$. It can be concluded that the effortless factor could be consider the strongest motivation to use mobile learning among the form six students.

On the contrary, this study found out that social influence insignificantly impacts on student usage of mobile learning $(\beta=0.05, p>0.05)$. In the context of this research, student's perception into the role of teachers, peers and family are investigated in term of influencing the use of mobile learning. The result showed inconsistent finding with Mosunmola et al. (2018); Nawi et al. (2019) and Huang \& Wu (2017). However, the findings are in line with Yakubu \& Dasuki (2019); Kissi et al. (2018) and Iqbal \& Qureshi (2012). These studies done in the developing country such as Ghana, Nigeria and Pakistan and could be conclude that mobile learning is still in an embryonic stage where influence of peers, teacher dan family still insufficient. The main reason could be the high cost of mobile devices and unavailability of supporting technology (Iqbal \& Qureshi, 2012). Instead, in Malaysia context the best probability due to over exposed into mobile devices, therefor the influence of peers, teachers and family become insignificant. Hence, the ownership and penetration rate of smartphone and internet is high, the using of mobile devices among students are usually common. As a result, the usage of mobile devices for learning are less influence by people surrounds.

Consistent with Kissi et al. (2018) and Mosunmola et al. (2018), this study has also found that facilitating condition as an essential predictor of mobile learning adoption $(\beta=0.17, \mathrm{p}<0.05)$. This finding suggests that student will not be motivated to use mobile learning without proper facilitating conditions. In the context of Malaysia, school are provided with internet access and computer lab to facilitate students and teachers doing online activities to support formal and informal learning activities. Even though certain places having unstable internet connection at school but they can access internet at home for sure. This relate to higher broadband and internet penetration rates among Malaysian. In year 2019, penetration rate for broadband and mobile-cellular among Malaysian are 127.1\% and 131.4\% each (MCMC, 2020). This figure verified that student in Malaysia having no problem in term of internet connectivity and ownership of mobile phone to proceed the mobile learning for the education purpose.

The results of this study also recognized, perceived playfulness as a significant predictor to mobile learning adoption $(\beta=0.09, \mathrm{p}<0.05)$. This finding further supports previous studies done by Masrek $\&$ Shahibi (2019); Nawi et al. (2019); Iqbal \& Qureshi (2012) and Chou (2006). The result suggest that the more students enjoy the mobile learning, the more they will be attracted to use mobile learning in their learning activities. Besides that, this finding justified the opinion of Bruner \& Kumar (2005); Moon \& Kim (2001) and Lin et al. (2005) that perceived ease of use have significant correlation to perceived playfulness. Their finding suggests an important way to increase fun or playful is to increase ease of use or effort expectancy. In the context of this study, students have significantly perceived that mobile learning are easy thus making the mobile learning system playful and enjoyable to interact with. As a result, perceived playfulness also has significant effect into mobile learning adoption. Therefore, mobile learning developers should react to this finding by enriching their applications, content and interaction with enjoyable and entertaining features. 
The last hypothesis of this study is between self-directed learning and mobile learning adoption. Compared to the previous study of UTAUT, this variable is not very extensively studied in the context of mobile learning. The result of this study has shown that this variable is indeed applicable in determining the usage of mobile learning $(\beta=0.48, p<0.05)$. Surprisingly, this variable become the most significant construct to explain the mobile learning adoption among the form six students (variance - 48\%). This result is in line with the finding of Masrek \& Shahibi (2019); Gu (2016); Karimi et al. (2016) and William \& Brown (2013). This finding suggests that individual with a highly autonomous learning ability will be more likely to use mobile learning than an individual with a lower autonomous learning ability. In the context of learning, this implied that learning should empower a student to become a free, mature, and authentic self (Savin et al. 2004). Also, the result in line with Knowles (1975) definition of self-directed learning as a process in which individuals take the initiative in diagnosing their learning needs, formulating goals, identifying material resources, choosing and implementing appropriate learning strategies. Based on Knowles, form six students already classified as an adult learner and not surprising they can control and put their own initiative in term of determine their learning strategies. For these reasons, teacher, family and school administrator could play their role to groom their students to be more independent and adapt themselves to be more self-learning.

\section{Conclusion}

This study identifies factors that influence students to adopt mobile learning in their learning. It takes the current literature forward by providing a link between UTAUT variable and learners' individual characteristics (Self-Directed Learning) to measures of mobile learning adoption. A model of mobile learning adoption is proposed and empirically tested. According to the finding, determinants of mobile learning adoption are different for form six students compare to students in higher institutions. For example, form six students more influence by Effort Expectancy rather than Performance Expectancy as usual among the university students (Mohd Azli et al. (2019); Nawi et al. (2019) and Thongsri et al. (2017). Thus, the practitioners and application developer should consider the level of difficulties of the program or app for the school purpose. This is to make sure the targeted group could benefit from online sources to increase the effectiveness of learning activities. On the other hand, finding suggested that Self-Directed Learning become the strongest predictor of mobile learning adoption. This is an abnormal scenario when UTAUT variable are having lower prediction power rather than the extension variable. Consequently, the researcher and practitioner should consider individual characteristic in term of predicting technology information system acceptance. Thus, to increase the prediction power, scholars could be considered to extend the existing technology acceptance model with others determinant based on the context of study.

This research also contributes to mobile learning adoption literature by introducing the Perceived Playfulness and Self-Directed Learning as an indicator. Results suggest that effortless and enjoyable factors are inter-correlated and significantly influence the usage of mobile learning while the individual characteristic (Self-Directed Learning) became the most influential mobile learning adoption among the form six student. It expands on Kreber's (1998) study, showing that Kolb's learning style framework has interesting implications for explaining individual differences in this self-directed learning environment. Students with higher independent level of learning might be more inclined to adopt this platform. However, this result only applied

The paper calls for further research on mobile learning adoption and its antecedents. It shows interesting results for the impact of student's and mobile platform characteristics on mobile learning adoption. However, due to its cross-sectional nature, causality should not be readily inferred. Future research may adopt a longitudinal approach to validate these cause-effect relations. For example, researchers should explore whether the role of playfulness and individual characteristic changes over time as m-learning usage becomes habitual. Other than that, other predictors could be included in the proposal model. For examples, student attitude (Botero et al. (2019), self-efficacy (Wang \& Xiao (2018) and Computer Literacy (Nistor et al. 2014). Besides that, researcher should take into consideration moderating effect such as gender, age and experiences. It is in this way that more intensive results could be achieved to explore possibilities of mobile learning and acceptance of learning in an online community. 


\section{References}

Adofo, S. (2013). Challenges And Coping Strategies Of Student Nursing Mothers In Tertiary Institutions In The Greater Accra Region Of Ghana (M.Phil). University of Ghana.

Abdullah, M. M., Sharif, M., Azman, H., \& Arshad, M. (2019). Mobile Learning Adoption among Tertiary Students. The Journal of Technology Management and Technopreneurship (JTMT), 7(1), $1-6$.

Abu-Al-Aish, A., \& Love, S. (2013). Factors influencing students' acceptance of mobile learning: An investigation in higher education. The International Review of Research in Open and Distributed Learning, 14(5), 82-107.

Ahmed, M. S. (2016). Technology acceptance of smartphones as mobile learning tools: A contextual comparative study of engineering and education colleges.

Ajzen, I., Fishbein, M., (1975), Belief, attitude, intention and behaviour: An introduction to theory and research, Addison-Wesley, Reading

Ajzen, I., \& Fishbein, M. (2000). Attitudes and the attitude-behaviour relation: Reasoned and automatic processes. European Review of Social Psychology, 11, 1-33.

Alam, T., \& Aljohani, M. (2020). M-Learning: Positioning the Academics to the Smart devices in the Connected Future. JOIV: International Journal on Informatics Visualization, 4(2), 76-79.

Alrawashdeh, Thamer A, Muhairat, Mohammad I, \& Alqatawnah, Sokyna M. (2012). Factors affecting acceptance of web-based training system: Using extended UTAUT and structural equation modeling. arXiv preprint arXiv: 1205.1904

Amzaourou, O., \& Oubaha, D. (2018). Investigating the cross-cultural dimensions of educational Web 2.0 acceptance: The case of Moroccan and American university students. Research in Comparative and International Education, 13(2), 319-341.

Ariffin, S. K., \& Lim, K. T. (2020, May). Investigating Factors Affecting Intention to Use Mobile Payment Among Young Professionals in Malaysia. In First ASEAN Business, Environment, and Technology Symposium (ABEATS 2019) (pp. 6-11). Atlantis Press.

Bandura, A., (1986), Social foundations of thought and action: A social cognitive theory, Prentice Hall, New Jersey.

Baptista, G., \& Oliveira, T., (2015). Understanding mobile banking: The unified theory of acceptance and use of technology combined with cultural moderators. Computers in Human Behaviour, 50, 418-430.

Botero, G. G., Questier, F., Cincinnato, S., He, T., \& Zhu, C. (2018). Acceptance and usage of mobile assisted language learning by higher education students. Journal of Computing in Higher Education, 30(3), 426-451.

Brata, A. H., \& Amalia, F. (2018). Impact Analysis of Social Influence Factor on Using Free Blogs as Learning Media for Driving Teaching Motivational Factor. In Proceedings of the 4th International Conference on Frontiers of Educational Technologies (pp. 29-33).

Casey, T., \& Wilson, E., (2012). Predicting uptake of technology innovations in online family dispute resolution services: An application and extension of the UTAUT. Computer in Human Behaviour, 28(6), 2034-2045.

Chou, J. P. C. (2006). Understanding user's perceived playfulness toward mobile information and entertainment services in New Zealand (Doctoral dissertation, Auckland University of Technology).

Chong, A. Y. L., (2013). Mobile commerce usage activities: The roles of demographic and motivation variables. Technological Forecasting and Social Change, 80(7), 1350-1359.

Chung, J., \& Tan, F. B. (2004). Antecedents of perceived playfulness: An exploratory study on user acceptance of general information-searching websites. Information \& Management, 41(7), 869881.

Curum, B., \& Khedo, K. (2019). AMBLE: A Context-Aware Mobile Learning Framework. EAI Endorsed Transactions on Context-Aware Systems and Applications, 6(19). 1-12.

Dakduk, S., Santalla-Banderali, Z., \& van der Woude, D. (2018). Acceptance of blended learning in executive education. SAGE Open, 8(3), 2158244018800647.

Davis, F. D., (1989). Perceived usefulness, perceived ease of use, and user acceptance of information technology. MIS Quarterly, 13(3), 319-339. 
Duarte, P., \& Pinho, J. C., (2019). A mixed methods UTAUT2-based approach to assess mobile health adoption. Journal of Business Research, 102, 140-150.

Durak, H. Y. (2019). Examining the acceptance and use of online social networks by preservice teachers within the context of unified theory of acceptance and use of technology model. Journal of Computing in Higher Education, 31(1), 173-209.

Erazo-Garzón, L., Patiño, A., Cedillo, P., \& Bermeo, A. (2019). CALMS: A Context-Aware Learning Mobile System Based on Ontologies. In 2019 Sixth International Conference on eDemocracy \& eGovernment (ICEDEG) (pp. 84-91).

Frost, J. (2013). Regression analysis: How do I interpret $r$-squared and assess the goodness-of-fit? [Web $\log$ post]. The Minitab Blog, 30.

Grant, M. M. (2019). Difficulties in defining mobile learning: Analysis, design characteristics, and implications. Educational Technology Research and Development, 67(2), 361-388.

$\mathrm{Gu}$, J. (2016). Understanding self-directed learning in the context of mobile Web 2.0-case study with workplace learners. Interactive Learning Environments, 24(2), 306-316.

Gupta, A., Dogra, N., \& George, B., (2018). What determines tourist adoption of smartphone apps? An analysis based on the UTAUT-2 framework. Journal of Hospitality and Tourism Technology, 9(1), 50-64.

Hadi F. Z. and Kishik, A. A. (2014). Acceptance of Mobile Learning Among University Students in Malaysia. Journal of Computing \& Organizational Dynamics 1(1).

Hair Jr, J. F., Sarstedt, M., Ringle, C. M., \& Gudergan, S. P. (2017). Advanced issues in partial least squares structural equation modeling. saGe publications.

Huang, W. D., \& Wu, C. G. (2017). Understanding motivational system in open learning: Learners' engagement with a Traditional Chinese-based open educational resource system. Educational Technology Research and Development, 65(6), 1495-1521.

Iqbal, S. and Qureshi, I. A. (2012). M-learning Adoption: A Perspective from a Developing Country. The International Review of Research in Open and Distance Learning, 13(3), 147-164.

Jalil, A.; Beer, M.; Crowther, P. (2015). Pedagogical requirements for mobile learning: A review on Mobile Learning task model. Jurnal Interact. Media Educ, 12, 1-17. [CrossRef].

Jambulingam, M. (2013). Behavioural Intention to Adopt Mobile Technology among Tertiary Students. World Applied Sciences Journal, 22(9), 1262-1271.

Jasperson, J., Carter, P. E., \& Zmud, R. W. (2005). A comprehensive conceptualization of the postadoptive behaviours associated with IT-enabled work systems. MIS Quarterly, 29(3), 525-557.

Jeng, D. J. F., \& Tzeng, G. H., (2012). Social influence on the use of clinical decision support systems: Revisiting the unified theory of acceptance and use of technology by the fuzzy DEMATEL technique. Computer and Industrial Engineering, 62(3), 819-828.

Jones, Kelvyn. (2016). Re: What is the acceptable r-squared value? Retrieved from: https://www.researchgate.net/post/what_is_the_acceptable_rsquared_value/57d2be49615e27f1605e6ff3/citation/download.

J.-W. Moon and Y.-G. Kim., (2001). Extending the TAM for the World-Wide-Web context. Information and Management, 38, 217-230.

Kaliisa, R.; Picard, M. (2017). A systematic review on mobile learning in higher education: The African perspective. Turkish Online J. Educ. Technol, 16, 1-18.

Karimi, S. (2016). Do learners' characteristics matter? An exploration of mobile-learning adoption in self-directed learning. Computers in Human Behavior, 63, 769-776.

Kim, S. S., Malhotra, N. K., \& Narasimhan, S., (2005). Two competing perspectives on automatic use: A theoretical and empirical comparison. Information Systems Research, 16(4), 418-432.

Kissi, P. S., Nat, M., \& Armah, R. B. (2018). The effects of learning-family conflict, perceived control over time and task-fit technology factors on urban-rural high school students' acceptance of video-based instruction in flipped learning approach. Educational Technology Research and Development, 66(6), 1547-1569.

Knowles, M. S. (1975). Self-directed learning: A guide for learners and teachers. New York: Association Press

Kukulska-Hulme, A., \& Traxler, J. (2007), Learning Design with Mobile and Wireless Technologies. In H. Beetham, \& R. Sharpe (Eds.), Rethinking Pedagogy for the Digital Age: Designing and Delivering E-learning, Routledge, London. 
Kumar, B. A., \& Chand, S. S. (2019). Mobile learning adoption: A systematic review. Education and Information Technologies, 24(1), 471-487.

Kumar, V. R., Lall, A., \& Mane, T. (2017). Extending the TAM model: Intention of management students to use mobile banking: Evidence from India. Global Business Review, 18(1), 238-249.

Lamptey, H.K.; Boateng, R. (2017). Mobile learning in developing countries: A synthesis of the past to define the future. Int. J. Soc. Behav. Educ. Econ. Bus. Ind. Eng, 11, 420-427.

Lin, C., Wu, S., \& Tsai, R. (2005). Integrating Perceived Playfulness into expectation-confirmation model for web portal context. Information \& Management, 42(5), 683-693.

Lowenthal, J. N. (2010). Using mobile learning: Determinates impacting behavioural intention. The American Journal of Distance Education, 24(4), 195-206.

Mabruri, H., Ahmadi, F., \& Suminar, T. (2019). The Development of Science Mobile Learning Media to Improve Primary Students Learning Achievements. Journal of Primary Education, 8(1), 108116.

Maita, I., Indrajit, R. E., \& Irmayani, A. (2018, April). Userbehaviour analysis in academic information system using unified theory of acceptance and use of technology (UTAUT). In Proceedings of the 2018 International Conference on Internet and e-Business (pp. 223-228).

Makoe, M. (2010). Linking mobile learning to the student-centred approach. Retrieved May 12, 2011, from http://www.checkpointelearning.com/article/8044.html

Masrek, M. N., \& Shahibi, M. S. (2019). Mobile Learning Adoption: The Case of Malaysian University Students. International Journal for e-Learning Security (IJeLS), 8(1), 574-564.

MCMC. (2020) Internet user survey -(Infografic). Pdf https://www.mcmc.gov.my/skmmgovmy/media/General/pdf/Internet-Users-Survey-2020(Infographic).pdf

Mohd Azli Yeop, Mohd Faiz Mohd Yaakob, Kung Teck Wong, Yahya Don, Farah Mohamad Zain. (2019). Implementation of ICT Policy (Blended Learning Approach): Investigating factors of Behavioural Intention and Use Behaviour. International Journal of Instruction, 12(1), 767-782.

Moon, J. W., \& Kim, Y. G. (2001). Extending the TAM for a World-Wide-Web context. Information \& Management, 38(4), 217-230.

Mosunmola, A., Mayowa, A., Okuboyejo, S., \& Adeniji, C. (2018). Adoption and use of mobile learning in higher education: the UTAUT model. In Proceedings of the 9th International Conference on EEducation, E-Business, E-Management and E-Learning (pp. 20-25).

Mustafa, N., Nordin, N. M., Embi, M. A., \& Norman, M. H. (2018). Testing the Usability of a Mobile Learning Module. International Journal of Engineering \& Technology, 7(4.21), 113-117.

Nassuora, A. B. (2013). Students Acceptance of Mobile Learning for Higher Education in Saudi Arabia. International Journal of Learning Management Systems, 1(1), 1-9.

Nawi, N. C., Mamun, A. A., Nasir, N. A. M., \& Muniady, R. (2019). Factors Affecting the Adoption of Social Media as a Business Platform: A Study among Student Entrepreneurs in Malaysia. Vision, 23(1), 1-11.

Nistor, N., Göğüs, A., \& Lerche, T. (2013). Educational technology acceptance across national and professional cultures: a European study. Educational Technology Research and Development, 61(4), 733-749.

Okai-Ugbaje, S., Ardzejewska, K., \& Imran, A. (2020). Readiness, roles, and responsibilities of stakeholders for sustainable mobile learning adoption in higher education. Education Sciences, $10(3), 49$.

Okai-Ugbaje, S.; Ardzejewska, K.; Imran, A. (2017). A systematic review of mobile learning adoption in higher education: The African perspective. I-Mang. J. Mob. Appl. Technol, 4, 1-13.

Oliver, R. L., (1980). A cognitive model of the antecedents and consequence of satisfaction decisions. Journal of Marketing Research, 17(4), 460-469.

Paetzold, Ramona. (2016). Re: Low $R$-squared values in multiple regression analysis? Retrieved from: https://www.researchgate.net/post/Low_Rsquared_values_in_multiple_regression_analysis/56f40be793553b1f9a11fcb3/citation/downloa d.

Park, J., Parsons, D., \& Ryu, H. (2010). To flow and not to freeze: Applying flow experience to mobile learning. Learning Technologies, IEEE Transactions on, 3(1), 56-67. 
Pedersen, P. E., \& Ling, R. (2003). Modifying adoption research for mobile Internet service adoption: Cross-disciplinary interactions. In Paper presented at the system Sciences, 2003. Proceedings of the 36th annual Hawaii international conference.

Pedro Isaias, Francisco Reis, Clara Coutinho, Jose Alberto Lencastre, (2017). Empathic technologies for distance/mobile learning: An empirical research based on the unified theory of acceptance and use of technology (UTAUT). Interactive Technology and Smart Education, 14(2), 159-180,

Ramakrishnan, K., Yasin, N. M., Selvaraj, K. R., \& Periyasamy, J. (2019). Building the Bridge between Higher Learning Institution and Social Media Technologies through Mobile Learning in Malaysia. International Journal of Engineering and Advanced Technology, 8(5C), 937-944.

Ramírez-Correa, P., Rondán-Cataluña, F. J., Arenas-Gaitán, J., \& Martín-Velicia, F., (2019). Analysing the acceptation of online games in mobile devices: An application of UTAUT2. Journal of Retailing and Consumer Services, 50, 85-93.

Rogers, E., (1962), Diffusion of innovation, Free Press, New York.

Ryan, R. M., and Deci, E. L. (2000). Intrinsic and extrinsic motivations: classic definitions and new directions. Contemp. Educ. Psychol, 25, 54-67.

Savin-Baden, M., \& Major, C. H. (2004). Foundations of problem-based learning. Berkshire: SRHE \& Open University Press.

Schofield, C. P., West, T. and Taylor E. (2011) Going Mobile In Executive Education How Mobile Technologies Are Changing The Executive Learning Landscape, Berkhamsted Hertfordshire Ashridge.

Shankar, A., \& Datta, B. (2018). Factors affecting mobile payment adoption intention: An Indian perspective. Global Business Review, 19(3_suppl), S72-S89.

Shorfuzzaman, M., Hossain, M. S., Nazir, A., Muhammad, G., \& Alamri, A. (2019). Harnessing the power of big data analytics in the cloud to support learning analytics in mobile learning environment. Computers in Human Behavior, 92, 578-588.

Sivathanu, B., (2019). Adoption of digital payment systems in the era of demonetization in India: An empirical study. Journal of Science and Technology Policy Management, 10(1), 143-171.

Stone, B. K., Scibilia, B., Pammer, C., Steele, C., \& Keller, D. (2013). Regression analysis: How do I interpret $R$-squared and assess the goodness-of-fit. Retrieved August, 2, 2018.

Suartama, I. K., Setyosari, P., Sulthoni, S., \& Ulfa, S. (2019). Development of an instructional design model for mobile blended learning in higher education. International Journal of Emerging Technologies in Learning (iJET), 14(16), 4-22.

Suki, N. M., \& Suki, N. M. (2019). Structural relationships in the embedding of role-play games in a class for Japanese language proficiency: Towards a Unified View. Technology, Knowledge and Learning, 24(1), 65-87.

Teo, T. S. H., Lim, V. K. G., \& Lai, R. Y. C., (1999). Intrinsic and extrinsic motivation in Internet usage. Omega, 27(1), 25-37

Thomas, T., Singh, L., \& Gaffar, K. (2013). The utility of the UTAUT model in explaining mobile learning adoption in higher education in Guyana. International Journal of Education and Development using ICT, 9(3).

Thompson, R. L., Higgins, C. A., \& Howell, J. M., (1991). Personal computing: Toward a conceptual model of utilization. MIS Quarterly, 15(1), 125-143.

Van Schaik, P. (2009). Unified theory of acceptance and use for websites used by students in higher education. Journal of Educational Computing Research, 40(2), 229-257.

Venkatesh, V., Morris, M., Davis, G., \& Davis, F., (2003). User acceptance of information technology: Toward a unified view. MIS Quarterly, 27(3), 425-478

Venkatesh, V., Thong, J. Y-L., Xu, X., (2012). Consumer acceptance and use of information technology: Extending the Unified Theory of Acceptance and Use of Technology. MIS Quarterly, 36(1), 157 178.

Wang, Y. S., Wu, M. C., \&Wang, H. Y. (2009). Investigating the determinants and age and gender differences in the acceptance of mobile learning. British journal of educational technology, l40(1), 92-118.

Wang, L., \& Xiao, J. (2018). Research on influencing factors of learners' intention of online learning behaviour in open education based on UTAUT model. In Proceedings of the 10th International Conference on Education Technology and Computers (pp. 92-98). 
DOI: https://doi.org/10.47405/mjssh.v5i12.563

Wang, H. Y., \& Wang, S. H., (2010). Predicting mobile hotel reservation adoption: Insight from a perceived value standpoint. International Journal of Hospitality Management, 29(4), 598-608.

Williams, B., \& Brown, T. (2013). A confirmatory factor analysis of the Self-Directed Learning Readiness Scale. Nursing \& health sciences, 15(4), 430-436.

Wong, S. M., Leong, C. M., \& Puah, C. H. (2020). Mobile internet adoption in Malaysian suburbs: The moderating effect of gender. Asian Journal of Business Research, 9(3).

Yakubu, M. N., \& Dasuki, S. I. (2019). Factors affecting the adoption of e-learning technologies among higher education students in Nigeria: A structural equation modelling approach. Information Development, 35(3), 492-502.

Yang, H. H., Feng, L., \& MacLeod, J. (2019). Understanding college students' acceptance of cloud classrooms in flipped instruction: integrating UTAUT and connected classroom climate. Joumal of Educational Computing Research, 56(8), 1258-1276.

Yip, M. H., Kee, C. Y., Lee, J. W., Lee, Y. J., \& Soh, Y. Y. (2018). Determinants of continuance intention of mobile learning among academicians in Malaysian private universities (Doctoral dissertation, UTAR).

Yu, Chian-Son. (2012). Factors affecting individuals to adopt mobile banking: Empirical evidence from the UTAUT model. Journal of Electronic Commerce Research, 13(2), 104-121.

Zhang, A., \& Cristol, D. (Eds.). (2019). Handbook of mobile teaching and learning. Springer. 